\title{
Rhizopalmoxylon nypoides - a new palm root from the Deccan Intertrappean beds of Sagar, Madhya Pradesh, India
}

\author{
P K Kathal ${ }^{1}$, Rashmi Srivastava ${ }^{2, *}$, R C Mehrotra ${ }^{2}$ and P O Alexander ${ }^{1}$ \\ ${ }^{1}$ Department of Applied Geology, Dr. Harisingh Gour University, Sagar 470 003, India. \\ ${ }^{2}$ Birbal Sahni Institute of Palaeobotany, 53 University Road, Lucknow 226 007, India. \\ *Corresponding author. e-mail: rashmi57.bsip@gmail.com
}

A new species of fossil palm rhizome having root-mat under the organ genus Rhizopalamoxylon (Rhizopalmoxylon nypoides sp. nov.) is reported. The specimen shows the closest resemblance with the modern monotypic genus Nypa Wurmb of the Arecaceae. The specimen was collected from the late Maastrichtian-early Danian sediments of Deccan Intertrappean beds, Mothi, Sagar district, Madhya Pradesh, India. Nypa is a mangrove palm naturally found in estuaries and swamps of the tropical region and represents one of the oldest records of the genus from the Deccan Intertrappean beds of central India. The abundance of palms, including $N y p a$ and previously recorded coastal and mangrove elements such as Acrostichum, Barringtonia, Cocos, Sonneratia and marine algae (Distichoplax and Peyssonellia) from the Deccan Intertrappean beds indicate marine influence and existence of tropical rainforest ecosystem in the vicinity of fossil locality in contrast to the deciduous forests occurring there at present.

\section{Introduction}

The Deccan Volcanic Province (DVP) of India is one of the largest continental flood basalts in the earth history. The Deccan traps were formed as a result of volcanic eruption and outpouring of lava in peninsular India; this was associated with the movement of Indian Plate over the hotspot located in the Reunion Island (Chatterjee et al. 2013). Recent studies based on ${ }^{40} \mathrm{Ar} / \mathrm{Ar}^{39}$ dating and magnetostratigraphy indicate that volcanism had extended duration of $67.5 \pm 1$ to $63 \mathrm{Ma}$ having a bulk eruption at $65 \pm 1 \mathrm{Ma}$ (Chenet et al. 2009; Renne et al. 2015; Schoene et al. 2015; Shrivastava et al. 2015). Deccan Intertrappean sediments were deposited during pauses or quiescent period of the volcanic activity in lacustrine and fluviatile environments. These sedimentary beds that occur sandwiched between successive lava flows are highly fossiliferous and contain diverse biota (both flora and fauna) of late Maastrichtian-early Danian age.

It has been observed that Deccan volcanism along with meteorite impact at Chicxulub, Mexico played a significant role in global climate change at the $\mathrm{K}-\mathrm{Pg}$ boundary and severely affected the existence of dinosaurs and planktic foraminifera (Khosla and Sahni 2003; Keller et al. 2009a, b). However, Couvreur et al. (2011) suggested a constant diversification of palms (Yule Process) in the tropical rain forest ecosystem until the Neogene. Our observations also suggest that palms along with other terrestrial angiosperms continued and diversified throughout $\mathrm{K}-\mathrm{Pg}$ boundary mass extinction event. 


\section{Material and method}

The general stratigraphic sequence of rocks of the Sagar district has been given by Rajarajan (1978). The oldest rock exposed in the area is sandstonequartzite of Rewa Group (Vindhyan Supergroup) of Neoproterozoic age, overlain by the flows of Deccan basalts (with Intertrappean beds) of late Maastrichtian-early Danian age.

The specimen of palm rhizome fossil, described here was collected from thin calcareous sandstone bed (late Maastrichtian-early Danian) of the Deccan Intertrappean (GPS coordinates of fossil recovery $23^{\circ} 57^{\prime} 35^{\prime \prime} \mathrm{N} ; 78^{\circ} 41^{\prime} 18^{\prime \prime} \mathrm{E}$ ), exposed between two basaltic flows (marked as Lower Flow and Upper Flow, Map 1), western slope of a Deccan Trap hill, at $582 \mathrm{~m}$ elevation, near Mothi, Sagar district, Madhya Pradesh, India (figure 1).

The cross sections of the fossil rhizome were prepared following the standard method of grinding, polishing and mounting in Canada balsam for permineralized material (Lacey 1963). The thin sections were examined and photographed under the high power light microscope (Leica DFC290). Thin sections of a number of modern genera of palm roots for comparison were examined at the Birbal Sahni Institute of Palaeobotany, Lucknow (BSIP). The type slides are deposited in the museum of the institute (BSIP). The anatomical terms used in describing the rhizome are those adopted by Tomlinson (1990) and Seubert (1996a, b).

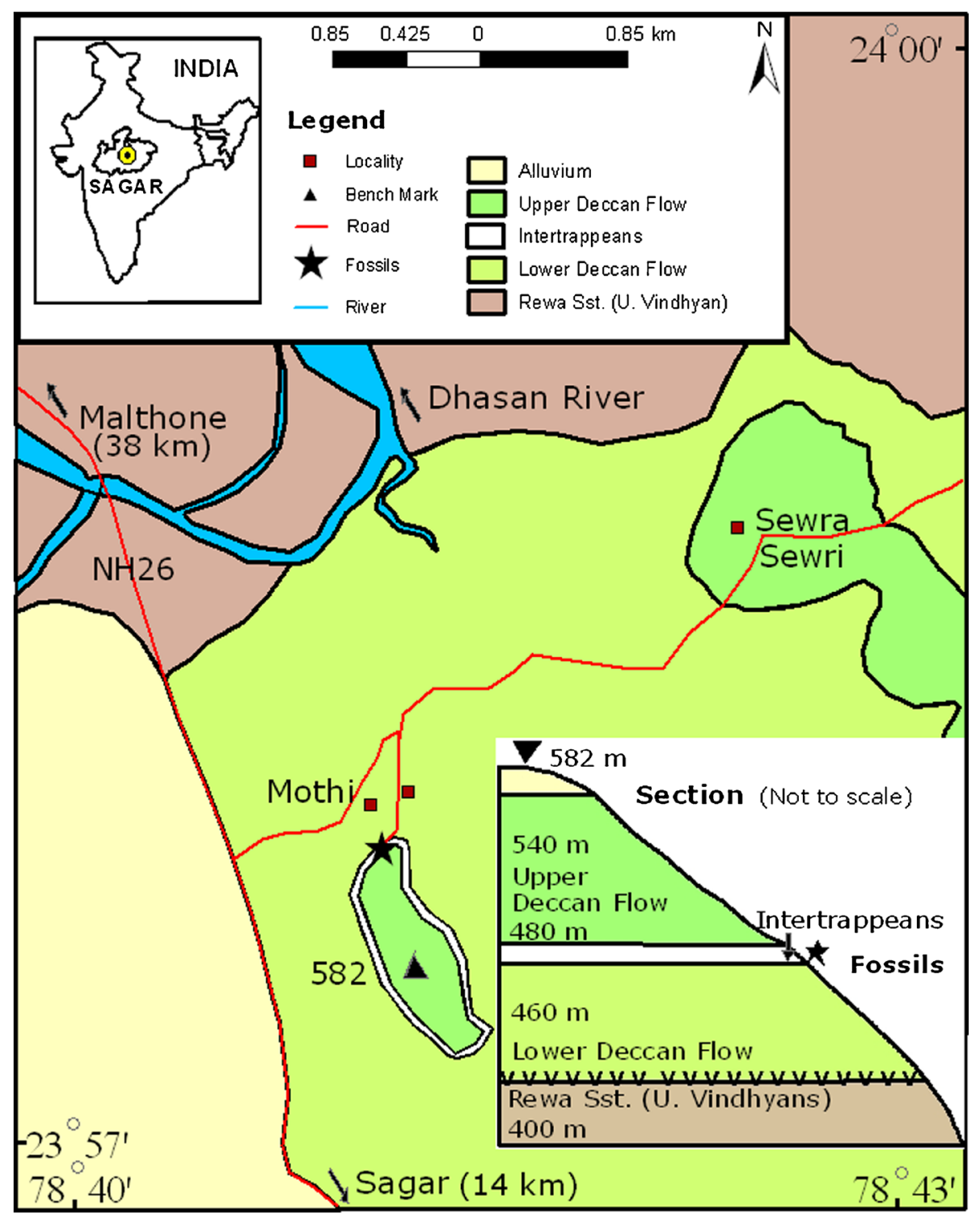

Figure 1. Geological map showing the fossil locality (marked by a star) near Mothi Village, Sagar district, Madhya Pradesh. 


\section{Systematic description}

Order: Arecales

Family: Arecaceae

Sufamily: Nypoideae

Genus: Rhizopalmoxylon Gothan (1942)

Rhizopalamoxylon nypoides Kathal et al., sp. nov. (figures 2, 3)

Specific diagnosis: Roots more than 15, about 2-3.5 $\mathrm{mm}$ in thickness, each divisible mainly into extrastelar and stelar regions. Extrastelar region made up of rhizodermis, exodermis, cortex and endodermis; stelar region comprising vascular bundles and pith. Rhizodermis single layered. Exodermis made up of 2-3 layers of horizontally elongated thick walled cells. Outer cortex about 350-450 $\mu \mathrm{m}$ thick, homogeneous. Inner cortex about $2 \mathrm{~mm}$ in thickness, aerenchymatous with well developed radially elongated air chambers or cavities in 1-3 rows; fibres absent. Endodermis present, about $35 \mu \mathrm{m}$ thick; cells thick walled. Vascular bundles radial and exarch. Xylem strands 25-28; protoxylem 15-30 $\mu \mathrm{m}$ in diameter; metaxylem arranged in 1 or 2 rows, 40-90 $\mu \mathrm{m}$ in diameter. Ground mass or conjunctive tissue made up of thin walled, radially elongated parenchymatous cells. Pith present, about $375 \mu \mathrm{m}$ in diameter, mostly represented by a cavity.

Repository: Birbal Sahni Institute of Palaeobotany, Lucknow, India.

Holotype: Specimen No. BSIP40974.

Horizon: Deccan Intertrappean beds of India.

Locality: Mothi, Sagar district, Madhya Pradesh, India.

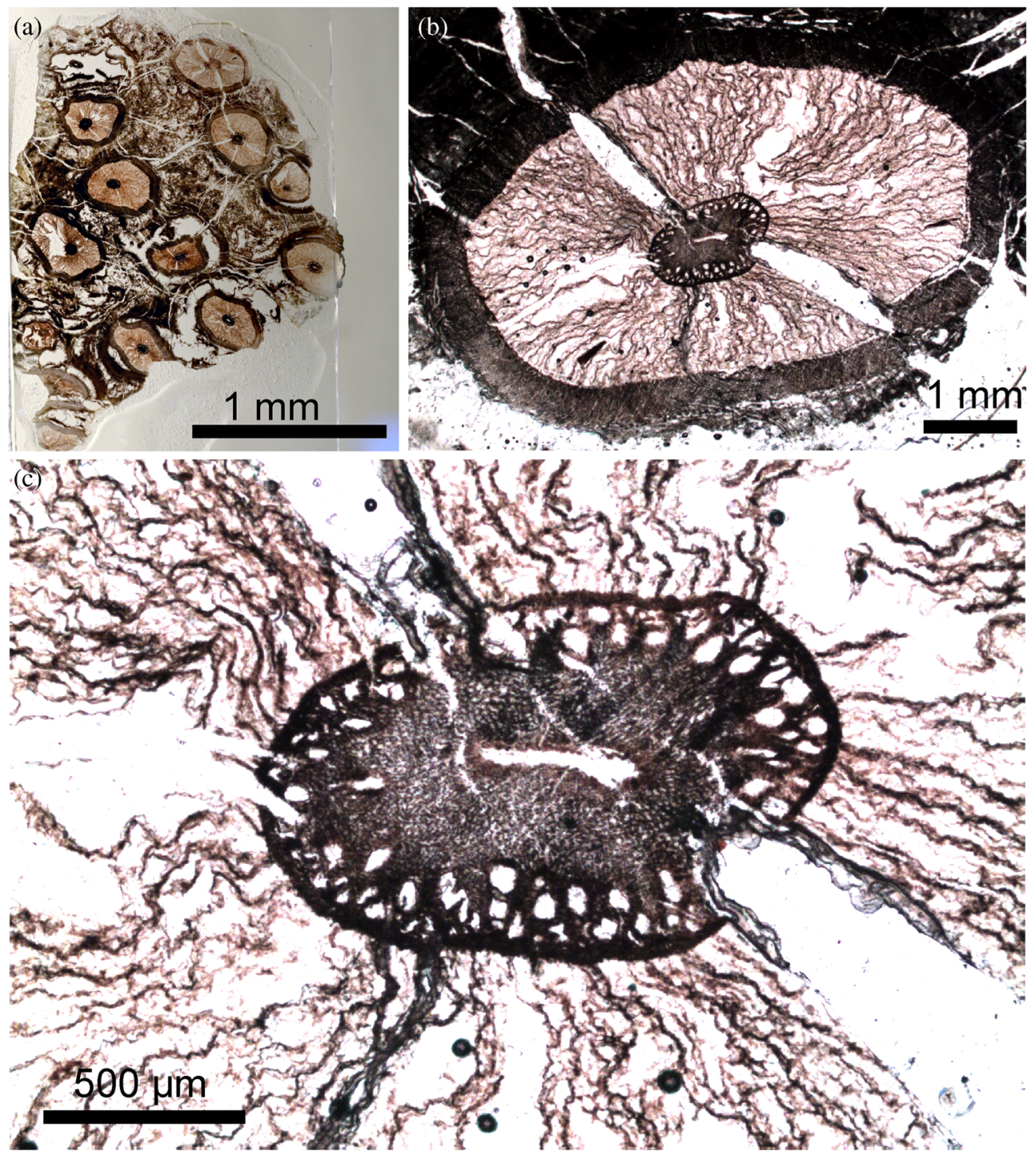

Figure 2. Rhizopalmoxylon nypoides Kathal et al., sp. nov. (a) A palm rhizome with root mat. (b) Transverse section of a root showing exodermis, aerenchymatous cortex and central steler region. (c) Same section magnified to show cortical air chambers and radial vascular bundles in the stelar region. 


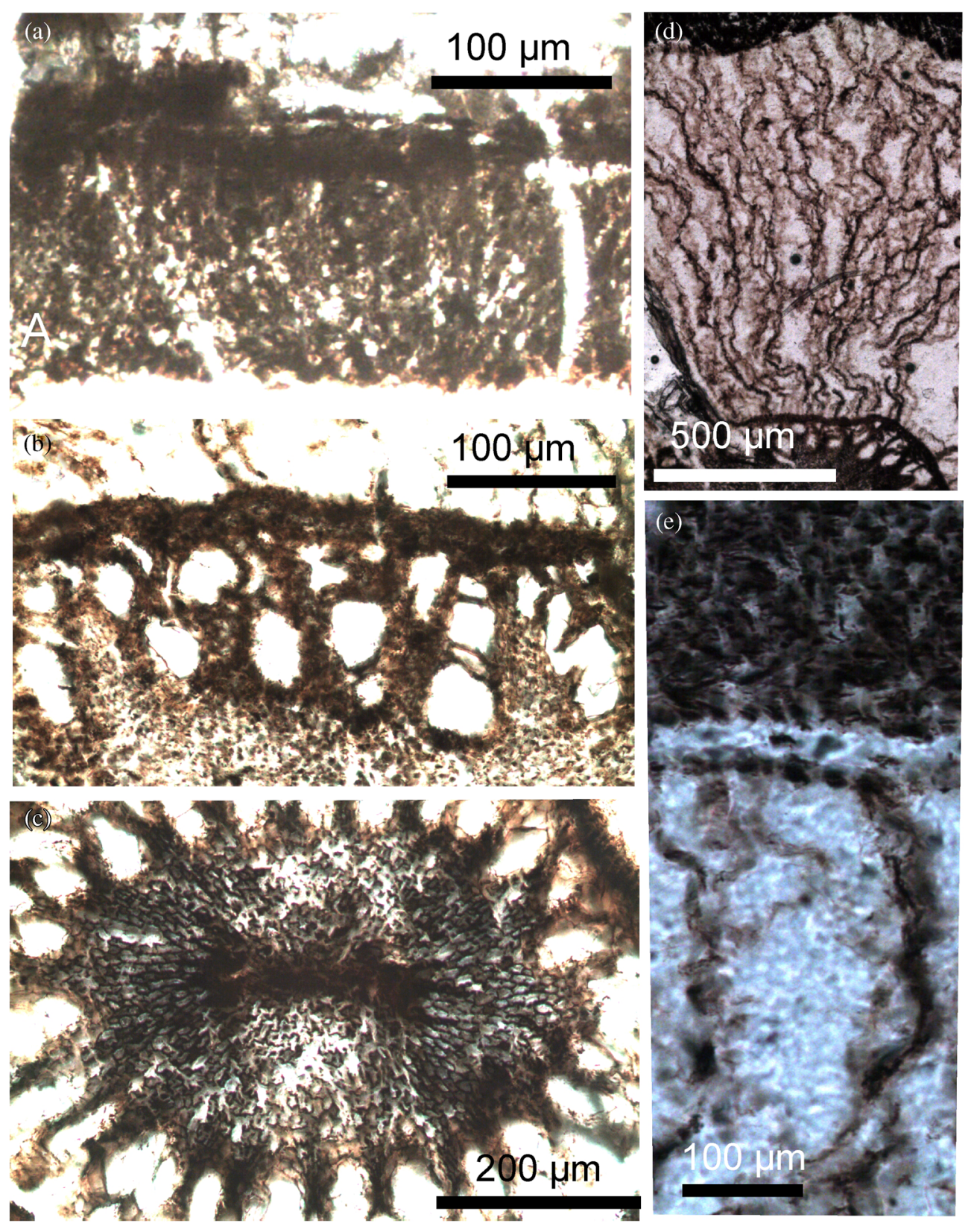

Figure 3. Rhizopalmoxylon nypoides Kathal et al., sp. nov. (a) A part of the section showing exodermis and outer cortex. (b) Magnified view of the stele showing endodermis and exarch xylem bundles. (c) Cross section of another root showing conjunctive tissue and parenchymatous pith. (d) Cross section of the root showing well developed radially elongated air chambers. (e) Showing an enlarged air cavity with narrow partition.

Age: Late Maastrichtian-early Danian.

Etymology: The specific epithet indicating its close resemblance with Nypa.

Description: The description is based on a chert piece comprising a rhizome having a large number of irregularly oriented roots forming the root mat.

There are more than 15 roots ranging about 2$3.5 \mathrm{~mm}$ in thickness. Each root is divisible mainly into extrastelar and stelar regions. The extrastelar region consists of rhizodermis, exodermis, cortex and endodermis, while the stelar region comprises vascular bundles and pith. The rhizodermis is single layered measuring about $283 \mu \mathrm{m}$ in thickness. Its cells are poorly preserved. The exodermis measures about $62 \mu \mathrm{m}$ in thickness and is made up of 2-3 layers of horizontally elongated thick walled cells. The outer cortex is homogeneous and about 350-450 $\mu \mathrm{m}$ thick; its cells are thick walled and polygonal in shape. The inner cortex, ranging 1.8-2.2 $\mathrm{mm}$ in thickness, is aerenchymatous with well developed radially elongated air chambers or cavities in 1-3 rows. The air cavities are separated from each other by usually one cell wide narrow 
partitions which often collapse. Fibres are absent in the inner cortex. The endodermis is present and measures about $35 \mu \mathrm{m}$ in thickness; its cells are thick walled. Vascular bundles are radial and exarch near the periphery. Xylem strands are 25-28 in number where protoxylem vary $15-28 \mu \mathrm{m}$ in diameter and metaxylem ranging $46-85 \mu \mathrm{m}$ in diameter are arranged in 1 or 2 rows. The phloem alternates with xylem strands, however, its cells are poorly preserved. A ground mass or conjunctive tissue is made up of thin walled, radially elongated parenchymatous cells which are about 13-23 $\mu \mathrm{m}$ in size. The pith measures about $378 \mu \mathrm{m}$ in diameter and is mostly represented by a cavity except in one root which is probably immature; its cells are poorly preserved, thin walled and 173-205 $\mu \mathrm{m}$ in size.

Affinities: Palm roots anatomically show a generalized pattern found in monocotyledons in having polyarch vascular tissue and absence of secondary thickening but unlike other monocots, are generally devoid of root hairs (Mahabale and Udwadia 1960; Tomlinson 1990). In order to find out nearest modern counterpart of the palm family Arecaceae, the fossil was compared with its various subfamilies (Dransfield et al. 2008), namely Arecoideae, Calamoideae, Ceroxyloideae, Coryphoideae and Nypoideae through the published description and photographs (Cormack 1896; Drabble 1904; Mahabale and Udwadia 1960; Tomlinson 1990; Seubert 1996a, b, 1997, 1998a, b; Chomicki et al. 2014). Arecoideae can be differentiated from our fossil in having lobed vascular cylinder, mechanical elements in the inner cortex and medullary bundles in the pith, while Calamoideae is distinct in possessing mucilage cells or fibres in the inner cortex with the occasional occurrence of medullary bundles. Both Ceroxyloideae and Coryphoideae differ from the present fossil in having medullary bundles, moreover, the former possesses fibres in the inner cortex. The present roots show nearest resemblance with the monotypic subfamily Nypoideae (Nypa fruicans Wurmb) in having large air chambers separated from each other by irregular vertical thin walled diaphragms/partitions, very small stelar region and absence of fibrous bundles in the cortex and medullary bundles in the pith. The fossil also differs from the modern Nypa in the absence of pericycle and in having slightly greater number of xylem strands which are up to 25 in the modern species (Mahabale and Udwadia 1960).

Comparison with fossil species: The genus Rhizopalmoxylon was informally instituted by Felix (1883) for fossil roots referable to the family
Arecaceae (Palmae) without any description/diagnosis Later on, Gothan (1942) validated the genus by providing description/diagnosis and described two species under Rhizopalmoxylon, However, later workers ignorant of Gothan's work referred their species to Rhizopalmoxylon Felix (1883). Many palm roots have also been assigned to the genus Palmoxylon Schenk (Stenzel 1904; Stockmans and Williere 1943; Shukla 1946; Lakhanpal 1955; Ogura 1962; Rao and Menon 1965; Menon 1968; Tidwell et al. 1971; Bonde et al. 2004), while some have been described without assigning any name (Verma 1974; Ambwani 1981).

So far, about 14 species of Rhizopalmoxylon Gothan (1942) are reported, viz., R. glaseli Gothan (1942), R. bohlenianum Gothan (1942), R. pilosum van der Burgh and Meulenkamp (1966), R. libycum Koeniguer (1970), R. behuninii Tidwell et al. (1972), R. blackii Tidwell et al. (1972), R. scottii Tidwell et al. (1972), R. sundaram Mahabale and Rao (1973), R. huepaciense Cevallos-Ferriz and Ricalde-Moreno (1995), R. teguachiense CevallosFerriz and Ricalde-Moreno (1995), $R$. borassoides Awasthi et al. (1996), R. singularis Bonde et al. (2009), R angiorhizon (= Palmoxylon angiorhizon Stenzel 1904) Bonde et al. (2009) and R. macrorhizon (= Palmoxylon macrorhizon Stenzel 1904) Bonde et al. (2009).

Rhizopalmoxylon glaseli Gothan, R. bohlenianum Gothan and $R$. singularis Bonde et al. differ from the present roots in having medullary bundles in the pith and distribution of air cavities in the cortical region. In $R$. behuninii Tidwell et al., $R$. blackii Tidwell et al., R. scottii Tidwell et al. rhizodermis and exodermis are not preserved. In $R$. behuninii and $R$. blackii, stele is bigger and metaxylem is arranged in three rows. $R$. scottii markedly differs in having fewer and smaller air cavities. In $R$. sundaram Mahabale and Rao endodermis is indistinct and larger number of vascular bundles (up to 45) are present. In $R$. huepaciense Cevallos-Ferriz and Ricalde Moreno, $R$. teguachiense Cevallos-Ferriz and Ricalde Moreno, and $R$. singularis, fibrous tissue is interspersed in the cortex. Borassoid palm roots (Ambwani 1981) differ in having larger number of vascular bundles (50-55) and presence of medullary bundles in the pith. $R$. borassoides Awasthi et al. can be differentiated in having sclerenchymatous outer cortex (hypodermis), 2-3 seriate partition walls and vascular strand in three rows. The root showing resemblance with Nypa reported by Verma (1974) compares well with the present specimen in having large air spaces separated by 1-2 celled thick septa or diaphragm, but differs also in possessing only 12-15 vascular bundles. Since the present roots are different from the earlier reported fossilized 
palm roots, a new species of Rhizopalmoxylon, Rhizopalmoxylon nypoides is established; the specific name is after the extant genus Nypa.

\section{Discussion}

Amongst monocotyledons, Arecaceae/Palmae is one of the largest families having monophyletic origin and has been placed within the Commelinid clade (Chase et al. 2006; Davis et al. 2006). Palms are pantropical in distribution and considered as an important and characteristic component of tropical rainforest ecosystem (Couvreur et al. 2011). Arecaceae consists of 201 genera and 2650 species distributed in five sub-families (Govaerts and Dransfield 2005; Mabberley 2005; Dransfield et al. 2008). The subfamily Nypoideae consists of a single monotypic genus Nypa Steck. On the basis of molecular phylogenetic analysis, subfamily Nypoideae is resolved as sister to all palms except Calamoideae by Asmussen et al. (2006), while other studies made by Uhl et al. (1995) and Lewis and Doyle (2001) consider Nypoideae as sister to all palms, including Calamoideae. In India, palms are represented today by about 20 genera, including Nypa comprising 96 species (Kulkarni and Mulani 2004).

The family Arecaceae is represented globally by richest fossil records. Harley (2006) listed fossil records of this family from all over the world. The earliest unambiguous fossils of the family are from the Upper Cretaceous of Europe and USA. They are in the form of costapalmate leaves named Sabalites. On the basis of oldest reliable megafossil records from Europe (Dransfield et al. 2008) and molecular phylogenetic studies (Couvreur et al. 2011), palms have been suggested to be of Laurasian origin. However, recent reports of pollen grains of Arecaceae from the Lower Cretaceous (Barremian-Albian) of Patagonia (Argentina) are the oldest records (Martínez Leandro et al. 2016) of the palm family. These records suggest the origin of monocots and a probably initial diversification of palms during the Early Cretaceous in high latitudes of Gondwana instead of Laurasia.

Phytogeographical and palaeoecological considerations: The genus Nypa Steck is monotypic with a single species $N$. fruticans Wurmb. It is strictly a mangrove palm presently growing on swampy coastline and estuaries of Indian and Pacific Oceans. It was introduced in West Africa and has now spread and naturalized in Cameroon, Panama and Trinidad (Dransfield et al. 2008). It does not occur on shores exposed to strong wave action and in hypersaline conditions (Tralau 1964; Collinson 1993). In India, it is commonly distributed in the Sundarbans in the eastern part of mangrove forest, on sides of tidal creeks and very often grows on intertidal flat lands and marshy places. It is also found in the Andaman and Nicobar Islands and southeast Asian countries (Naskar and Mandal 1999a, b). In addition to Nypa, the other important palm fossil known from the intertrappean beds of Sagar is Palmoxylon sundaram (Sahni 1946; Bonde et al. 2004) resembling Cocos L., which is native to coastal areas. The presence of Nypa, along with Cocos in Sagar suggests a warm and humid climate with marine influence, similar to that found in the Sunderbans at present.

The fossil records of Nypa are known from both tropical and temperate zones such as Africa, America, Asia and a number of European countries, mostly in the Late Cretaceous, Paleocene and Eocene. The fossils of the genus reduced gradually during the middle Miocene due to climatic deterioration (Tralau 1964; Morley 2000; Gee 2001; Harley 2006; Dransfield et al. 2008; Gomez-Navarro et al. 2009). The oldest records are known from the late Maastrichtian-early Danian sediments of the Deccan Intertrappean of India (Sahni and Rode 1937; Lakhanpal 1952; Chitaley 1960; Nambudiri 1966; Verma 1974; Chitaley and Nambudiri 1995). The occurrence of Nypa, along with the known coastal and mangrove fossil records like Acrostichum (Bonde and Kumaran 2002), Barringtonia (Srivastava et al. 2009) Cocos (Srivastava and Srivastava 2014), Sonneratia (Srivastava 2008) and marine algae, Distichoplax and Peyssonellia (Bande et al. 1981) from the same horizon indicates marine seaway (an arm of Tethys sea) up to central India. This marine seaway model in central India was proposed by Lakhanpal (1970) and was further substantiated by palaeontological evidences (Sahni 1983; Bajpai 2009; Keller et al. $2009 \mathrm{a}, \mathrm{b})$. In India, Nypa is reported from the following younger horizons also: Eocene of Meghalaya (Bhattacharyya 1983) and Nagaland (Mehrotra et al. 2007), Oligocene of Assam (Mehrotra et al. 2003) and Miocene of Meghalaya (Lakhanpal 1952), Mizoram (Mehrotra et al. 2003) and Maharashtra (Kulkarni and Phadtare 1980). During the Late Cretaceous, India was already separated from rest of the Gondwanan continents, but yet not collided with Asia and had southern latitudinal position. The fossil locality was situated at $\sim 17^{\circ} \mathrm{S}$ palaeolatitude (ODSN), which is in contrast to its present day location, i.e., $23^{\circ} 40^{\prime} 52^{\prime \prime} \mathrm{N}$. The fossil records indicate that the continent of Africa and India possessed richer palm flora in the past (Srivastava et al. 2014). In their study on Araceae biogeography, Nauheimer et al. (2012) came to the conclusion that the ancestral area of Aroideae might have been either Asia or Africa. It appears that India played an important role in the dispersal of Arecaceae, Araceae, Connaraceae, 
Dipterocarpaceae, Oleaceae, Vitaceae and many other families (Dutta et al. 2011; Manchester et al. 2013; Shukla et al. 2013; Shukla and Mehrotra 2014; Srivastava et al. 2015; Baas et al. 2017); this supports 'Out of India' hypothesis, according to which the dispersal of many families from India into southeast Asia took place when they came on rafting with the Indian plate from south to north (Shukla et al. 2016).

\section{Acknowledgements}

The authors are thankful to the students of Bachelor of Science of Dr. Harisingh Gour University, Sagar for their help in collecting specimens of fossils and Prof. R P Tiwari, Vice Chancellor, Dr. Harisingh Gour University, Sagar, for overall support to carry out this study. Two of them (RS and RCM) are thankful to Prof. Sunil Bajpai, Director, Birbal Sahni Institute of Palaeobotany, Lucknow, for permission to publish the paper. Authors thank Jemini Khatik for cartographic help in developing the geological map and sections therein.

\section{References}

Ambwani K 1981 Borassoid fossil palm root from the Deccan Intertrappean beds of Nawargaon, Wardha district, Maharashtra; Geophytol. 11 13-15.

Asmussen C B, Dransfield J, Deickmann V, Barfod A S, Pintaud J-C and Baker W J 2006 A new subfamily classification of the family (Arecaceae): Evidence from plastid DNA phylogeny; Bot. J. Linn. Soc. 151 15-38.

Awasthi N, Mehrotra R C and Khare E G 1996 A borassoid palm root from the Deccan Intertrappean beds of Wardha district, Maharashtra with critical remarks on fossil roots of Eichhornia; Geophytol. 26 57-61.

Baas P, Manchester S R, Wheeler E A and Srivastava R 2017 Fossil wood with dimorphic fibres from the Deccan Intertrappean beds of India - the oldest fossil Connaraceae?; IAWA J. 38(1) 124-133.

Bajpai S 2009 Biotic perspective of the Deccan volcanism and India-Asia collision: Recent advances; In: Current Trends in Science, Platinum Jubilee Special Publication (ed.) Mukunda N (Bangalore: Indian Acad. Sci.), pp. 505-516.

Bande M B, Prakash U and Bonde S D 1981 Occurrence of Peyssonnelia and Distichoplax in the Deccan Intertrappeans with remarks on the age of Chhindwara traps and palaeoecology of the region; Geophytol. 11 182-188.

Bhattacharyya B 1983 Fossil plants from the Tura Formation (Eocene) in the Garo Hills, Meghalaya; Indian J. Earth Sci. 10 1-10.

Bonde S D and Kumaran K P N 2002 A permineralised species of mangrove fern Achrostichum from the Deccan Intertrappean beds of India; Rev. Palaeobot. Palynol. 120 285-299.

Bonde S D, Gamre P G and Mahabale T S 2004 Further contribution to Palmoxylon (Cocos) sundaram Sahni: Structure of the rooting base and its affinities; In: Vistas in palaeobotany and plant morphology: Evolutionary and environmental perspectives (Prof. D D Pant Memorial Volume) (ed.) Srivastava P C (Lucknow: U.P. Offset), pp. 229-235.

Bonde S D, Chate S V and Gamre P G 2009 Rhizopalmoxylon singulare sp. nov. - coralloid palm roots from the Late Cretaceous Deccan Intertrappean beds of Nawargaon, India; Palaeobotanist 58 57-65.

Cevallos-Ferriz S R S and Ricalde-Moreno O S 1995 Palmeras fosiles del norte de Mexico; An. Inst. Biol. Univ. Nac. Auton. Mex. Ser. Bot. 66 37-106.

Chase M W, Fay M F, Devey D S, Maurin O, Ronsted N, Davies J and Pillon Y 2006 Multigene analyses of monocot relationships: A summary; Aliso 22 63-75.

Chatterjee S, Goswami A and Scotese C R 2013 The longest voyage: Tectonic, magmatic, and palaeoclimatic evolution of Indian plate during its northward flight from Gondwana to Asia; Gondwana Res. 23 238-267.

Chenet A-L, Courtillot V, Fluteau F, Gerard M, Quidelleur $\mathrm{X}$, Khadri S F R, Subbarao K V and Thordarson T 2009 Determination of rapid Deccan eruptions across the Cretaceous-Tertiary boundary using paleomagnetic secular variation: 2. Constraints from analysis of eight new sections and synthesis for a $3500 \mathrm{~m}$ thick composite section; J. Geophys. Res. 114 B06103, doi: 10.1029/2008JB005644.

Chitaley S D 1960 A new specimen of Nypa fruit from Mohgaon cherts; Nature 186495.

Chitaley S D and Nambudiri E M V 1995 Anatomy of Nypa fruits reviewed from new specimens from the Deccan Intertrappean flora of India; In: Proceedings of symposium on global environment and diversification of plants through geological time, Birbal Sahni Centenary Volume (ed.) Pant D D (Allahabad: Society of Indian Plant Taxonomists), pp. 83-94.

Chomicki G, Bidel L P R, Baker W J and Jay-Allemand C 2014 Palm snorkelling: Leaf bases as aeration structures in the mangrove palm (Nypa fruticans); Bot. J. Linn. Soc. $174257-270$.

Collinson M E 1993 Taphonomy and fruiting biology of recent and fossil Nypa; In: Studies in palaeobotany and palynology in honour of Prof. W G Wagner, FRS Special paper in Palaeontology No. 49 (eds.) Collinson M E and Scott A C (London: The Palaeontological Association), pp. $165-180$.

Cormack B G 1896 On polystelic roots of certain palms; Trans. Linn. Soc. London., Ser. 225 275-286.

Couvreur T L P, Forest F and Baker W J 2011 Origin and global diversification patterns of tropical rain forests: Inferences from a complete genus-level phylogeny of palms; BMC Biol. 944.

Davis J I, Petersen G, Seberg O, Stevenson D W, Hardy C R, Simmons M P, Michelangeli F A, Goldman D H, Campbell L M, Specht C D and Cohen J 2006 Are mitochondrial genes useful for the analysis of monocot relationships? Taxon $\mathbf{5 5} 857-870$.

Drabble E 1904 On the anatomy of roots of palms; Trans. Linn. Soc., London Ser. 226 427-490.

Dransfield J, Uhl N W, Asmussen C B, Baker W J, Harley M M and Lewis C E 2008 Genera Palmarum: The evolution and classification of palms (Kew: Key Publishing, Royal Botanic Gardens).

Dutta S, Tripathi S M, Mallik M, Mathews R P, Greenwood P F, Rao M R and Summons E 2011 Eocene out-of-India dispersal of Asian dipterocarps; Rev. Palaeobot. Palynol. 166 63-68.

Felix J 1883 Die fossilen Holzer Westindiens; Sammlung Palaeontologie Abhandlungen Ser. I, pp. 1-27.

Gee C T 2001 The mangrove palm Nypa in the geologic past of the New World; Wetlands Ecol. Manag. 9 181-203. 
Gomez-Navarro C, Jaramillo C, Herrera F, Wing S L and Calljas R 2009 Palms (Arecaceae) from a Palaeocene rainforest of northern Colombia; Am. J. Bot. 96 13001312.

Gothan W 1942 Uber Palmenwurzelholzer aus der Brunkohle von Bohlen (Sachsen); Z. Geschiebeforsch. 18 $2-14$.

Govaerts R and Dransfield J 2005 World checklist of palms (Kew: Royal Botanic Gardens).

Harley M M 2006 A summary of fossil records for Arecaceae; Bot. J. Linn. Soc. 151 39-67.

Keller G, Adatte T, Bajpai S, Mohabey D M, Widdowson M, Khosla A, Sharma R, Khosla S C, Getsch B, Fleitmann D and Sahni A 2009a K-T transition in Deccan Traps of central India marks major marine seaway across India; Earth Planet. Sci. Lett. 282 10-23.

Keller G, Sahni A and Bajpai S 2009b Deccan volcanism, the KT mass extinction and dinosaurs; J. Biosci. 34(5) 709-728.

Khosla A and Sahni A 2003 Biodiversity during the Deccan volcanic eruptive episode; J. Asian Earth Sci. 21 895-908.

Koeniguer J C 1970 Sur quelques structures de Palmiers du Mio-Pliocene du Lybie; 94th Congr. Nat. Soc. Sav., Paris, Sci., Pau, 1969, III 175-189.

Kulkarni A R and Mulani R M 2004 Indigenous palms of India; Curr. Sci. 86(12) 1598-1603.

Kulkarni A R and Phadtare N R 1980 Leaf epidermis of Nypa from lignitic beds of Ratnagiri district, Maharashtra; Geophytol. 10 125-128.

Lacey W S 1963 Palaeobotany technique; In: Viewpoint in Biology 2 (eds) Carthey J D and Duddington I (London: Butterworths), pp. 202-243.

Lakhanpal R N 1952 Nipa sahnii, a palm fruit in the Tertiary of Assam; Palaeobotanist 1 289-294.

Lakhanpal R N 1955 Palmoxylon surangei, a new species of petrified palms from the Deccan Intertrappean Series; Palaeobotanist 4 15-21.

Lakhanpal R N 1970 Tertiary floras of India and their bearing on the historical geology of the region; Taxon 19 675-694.

Lewis C E and Doyle Jeff J 2001 Phylogenetic utility of the nuclear gene malate synthase in the palm family (Arecaceae); Mol. Phylogenet. Evol. 19 409-420.

Mabberley D J 2005 The plant book, a portable dictionary of the vascular plants (Cambridge: Cambridge University Press).

Mahabale T S and Rao S V 1973 Fossil flora of Rajahmundry area; In: Proceedings of the Symposium on Deccan Trap Country (ed.) Mahabale T S, INSA Bull. 45 192-214.

Mahabale T S and Udwadia N N 1960 Studies on palmsPart IV. Anatomy of palm roots; Proc. Nat. Inst. Sci. 26B 73-104.

Manchester S R, Kapgate D K and Wen J 2013 Oldest fruits of the grape family (Vitaceae) from the Late Cretaceous Deccan cherts of India; Am. J. Bot. 100(9) 1849-1859.

Martínez Leandro C A, Archangelsky S, Prámparo Mercedes B and Archangelsky A 2016 Early Cretaceous palm pollen tetrads from Patagonia, Argentina; Cret. Res. 59 129139.

Mehrotra R C, Tiwari R P and Mazumder B I 2003 Nypa megafossils from the Tertiary sediments of northeast India; Geobios 36 83-92.

Mehrotra R C, Paul A K and Verma S K 2007 Plant remains from the Disang Group of Wokha District, Nagaland, India; Curr. Sci. 92(5) 597-598.

Menon V K 1968 On a new petrified palm wood from Mohgaonkalan area; Palaeobotanist 16 197-205.

Morley R J 2000 Origin and evolution of tropical rain forests (Chichester: John Wiley and Sons Ltd.)
Nambudiri E M V 1966 More Nypa fruits from Deccan Intertrappean beds of Mohgaon Kalan; Curr. Sci. 36 421422.

Naskar K and Mandal R 1999a Ecology and biodiversity of Indian Mangroves; Part I: Global status (Delhi: Daya Publishing House).

Naskar K and Mandal R 1999b Ecology and biodiversity of Indian Mangroves; Part II: Morpho-anatomy of Mangroves (Delhi: Daya Publishing House).

Nauheimer L, Metzler D and Renner S S 2012 Global history of the ancient monocot family Araceae inferred with models accounting for past continental positions and previous ranges based on fossils; New Phytol. 195 938-950.

Ogura Y 1962 A fossil palm in Kenroku Park at Kanazawa; Trans. Proc. Palaeont. Soc. Japan, N.S. 8 223-230.

Rajarajan K 1978 Geology of Sagar district and western part of Damoh district, Madhya Pradesh; Geol. Surv. India Memoir. 109 1-99.

Rao A R and Menon V K 1965 A new species of petrified palm stem from the Deccan Intertrappean Series; Palaeobotanist 14 256-263.

Renne P R, Sprain C J, Richards M A, Self S, Vanderkluysen L and Pande K 2015 State shift in Deccan volcanism at the Cretaceous-Paleogene boundary, possibly induced by impact; Science 350(6256) 76-78.

Sahni B 1946 A silicified Cocos-like palm stem, Palmoxylon (Cocos)sundaram, from the Deccan Intertrappean beds; J. Indian Bot. Soc. 26 361-374.

Sahni A 1983 Upper Cretaceous palaeobiogeography of peninsular India and the Cretaceous-Paleocene transition: The vertebrate evidence; In: Cretaceous of India (ed.) Maheshwari H K (Lucknow: Indian Association of Palynostratigraphers), pp. 128-140.

Sahni B and Rode K P 1937 Fossil plants from intertrappean beds of Mohgaonkalan, in the Deccan, with a sketch geology of Chhindwara District; Proc. Nat. Acad. Sci. India 7 165-174.

Schoene B, Samperton K M, Eddy M P, Keller G, Adatte T, Bowring S A, Khadri S F R and Brian Gertsch 2015 U$\mathrm{Pb}$ geochronology of the Deccan Traps and relation to the end-Cretaceous mass extinction; Science 347 183-184.

Seubert E 1996a Root anatomy of palms. II: Calamoideae; Feddes Repert 107 43-59.

Seubert E 1996b Root anatomy of palms. III: Ceroxyloideae, Nypoideae, Phytelepheae; Feddes Repert 107 597-619.

Seubert E 1997 Root anatomy of palms. I: Coryphoideae; Flora 192 81-103.

Seubert E 1998a Root anatomy of palms. IV: Arecoideae, Part I. General remarks and description of the roots; Feddes Repert 109 89-127.

Seubert E 1998b Root anatomy of palms. IV: Arecoideae, Part II. Systematic implications; Feddes Repert 109 231-247.

Shukla A and Mehrotra R C 2014 Paleoequatorial rain forest of western India during the EECO: Evidence from Uvaria L. fossil and its geological distribution pattern; Hist. Biol. 26(6) 693-698.

Shukla A, Mehrotra R C and Guleria J S 2013 Emergence and extinction of Dipterocarpaceae in western India with reference to climate change: Fossil wood evidences; J. Earth Syst. Sci. 122(5) 1373-1386.

Shukla A, Mehrotra R C, Spicer R A and Spicer T E V 2016 Aporosa Blume from the paleoequatorial rainforest of Bikaner, India: Its evolution and diversification in deep time; Rev. Palaeobot. Palynol. 232 14-21.

Shukla V B 1946 Palmoxylon sclerodermum Sahni from the Eocene beds of Nawargaon, Wardha District, C.P.; J. Indian Bot. Soc. 25 105-116. 
Srivastava R 2008 Fossil woods resembling Sonneratia with fungal infection from Deccan Intertrappean sediments of Seoni District, Madhya Pradesh; Geophytol. 37 87-92.

Srivastava R and Srivastava G 2014 Fossil fruit of Cocos L. (Arecaceae) from Maastrichtian-Danian sediments of central India and its phytogeographical significance; Acta Palaeobot. 54 67-75, doi: 10.2478/acpa-2014-0003.

Srivastava R, Kapgate D K and Chatterjee S 2009 Permineralised fungal remains in the fossil wood of Barringtonia from the Deccan Intertrappean sediments of Yavatmal District, Maharashtra, India; Palaeobotanist $\mathbf{5 8}$ 11-19.

Srivastava R, Srivastava G and Dilcher D L 2014 Coryphoid palm leaf fossils from the Maastrichtian-Danian of central India with remarks on phytogeography of the Coryphoideae (Arecaceae); PLoS ONE 9(11) e111738.

Shrivastava J P, Duncan R A and Kashyap M 2015 Post$\mathrm{K} / \mathrm{PB}$ younger $40^{\mathrm{Ar}}-39^{\mathrm{Ar}}$ ages of the Mandla lavas: Implications for the duration of the Deccan volcanism; Lithos 224 214-224.

Srivastava R, Wheeler E A, Manchester S R and Baas P 2015 Wood of Oleaceae from the latest Cretaceous of India the earliest Olive branch?; IAWA J. 36 443-451.

Stenzel K G 1904 Fossilen Palmenholzer; Beitrage Palaontologie und Geologie Osterreichungars und des Orients 16 107-288.
Stockmans F and Williere Y 1943 Palmoxylons paniseliens de la Belgique; Mem. Musee Royal d' Histoire Naturelle de Belgique 100 1-75.

Tidwell W D, Simper A D and Medlyn D A 1972 A Palmoxylon from the Green River Formation (Eocene) of Eden Valley, Wyoming; Botanique 2 93-102.

Tidwell W D, Medlyn D A and Thayn G F 1972 Fossil palm materials from the Tertiary Dipping Vat Formation of central Utah; Great Basin Naturalist 32 1-15.

Tomlinson P B 1990 The Structural Biology of Palms (Oxford: Clarendon Press).

Tralau H 1964 The genus Nypa van Wurmb; Kungl. Sven. Vetensk. Acad. Handl. 5 5-29.

Uhl N W, Dransfield J, Davis I, Luckow M A, Hansen K S and Doyle J J 1995 Phylogenetic relationship among palms: Cladistic analyses of morphological and chloroplast DNA restriction site variation; In: Monocotyledons: Systematic and evolution (eds) Rudall P J, Cribb P J, Cutler D F and Humphries (Kew: Royal Botanic Garden), pp. 623-661.

van der Burgh J and Meulenkamp J E 1966 Über einige fossile Palmenartige Hölzer aus den östlichen Niederlanden; Acta Bot. Neerl. 15 276-283.

Verma C L 1974 Occurrence of fossil Nypa root from the Deccan Intertrappean beds of M. P., India; Curr. Sci. 43 289-290.

MS received 6 May 2016; revised 9 December 2016; accepted 2 January 2017

Corresponding editor: Pratul K Saraswati 